\title{
Free and total plasma theophylline concentrations in chronic airflow obstruction
}

\author{
P EBDEN, D LEOPOLD, AP SMITH, D BUSS, PA ROUTLEDGE \\ From the Department of Tuberculosis and Chest Diseases, Llandough Hospital, Penarth; and the Department \\ of Pharmacology and Therapeutics, Welsh National School of Medicine, Cardiff
}

ABSTRACT It has been suggested that the variability in clinical response between individuals at any given total plasma theophylline concentration may be related to interpatient variability in theophylline plasma protein binding. We therefore measured the plasma protein binding of theophylline in plasma from 39 outpatients with chronic airflow obstruction who were receiving long term oral theophylline treatment. The protein binding was measured at $37^{\circ} \mathrm{C}$ and $\mathrm{pH} 7.4 \mathrm{by}$ equilibrium dialysis. Total plasma theophylline concentration was measured by high performance liquid chromatography and the free concentration calculated by multiplying total concentration by the free (unbound) fraction. The total plasma theophylline concentration varied from 0.7 to $22.0 \mu \mathrm{g} / \mathrm{ml}$, mean 10.6 (SD 5.3) $\mu \mathrm{g} / \mathrm{ml}(3.9-121 \mu \mathrm{mol} / \mathrm{l}$, mean $58.3(29 \cdot 2) \mu \mathrm{mol} / \mathrm{l})$. The free fraction of theophylline varied only from 0.58 to 0.69 (mean $0.626(0.024)) \mu \mathrm{g} / \mathrm{ml}$ and was not related to the total concentration $(\mathrm{r}=-0.236, \mathrm{n}=39, \mathrm{p}>0.05)$. There was a very close relationship between free and total plasma concentrations $(r=0.996, n=39, p<0.001)$. It is concluded that there is little variability in plasma protein binding of theophylline in patients with chronic airflow obstruction. Other factors appear to be responsible for variability between individuals in the response to a given total plasma theophylline concentration.

Theophylline preparations are used in the management of airways obstruction and measurement of total plasma concentrations of the drug has been used as a guide to treatment. Theophylline is found in the blood as both free drug and drug bound to albumin. There is a wide variability in the clinical response of patients to any given total plasma theophylline concentration. Lesko and coworkers ${ }^{1}$ have recently claimed that the percentage of drug in the free form can vary up to fourfold in patients with chronic obstructive lung disease and that this could be responsible for much of the variability in response. We therefore examined the plasma protein binding of theophylline in a group of patients with chronic airflow obstruction who were receiving long term treatment and related the plasma protein binding differences to known determinants of the binding, such as albumin and non-esterified fatty acids. $^{2}$

Address for reprint requests: Dr PA Routledge, Department of Pharmacology and Therapeutics, Welsh National School of Medicine, Cardiff CF4 4XN.

Accepted 4 January 1984

\section{Methods}

Thirty nine outpatients (13 male) who were judged by their physicians to require continuous oral theophylline treatment were studied. The patients' diagnoses included asthma and chronic bronchitis or emphysema (or both), and their age range was 18-80 years. The theophylline preparations used included Nuelin SA, Ronaslophylline, Theocontin, and the aminophylline preparation Phyllocontin (which contains $78 \%$ theophylline). Concurrent medication included prednisolone, beclomethasone dipropionate and salbutamol by inhalation, frusemide, bendrofluazide, amiloride with hydrochlorothiazide (Moduretic), clonidine, methyldopa, isosorbide, dothiepin, and lorazepam.

Blood was taken with the patient's consent, by direct venepuncture with polypropylene syringes, and was transferred to polyethylene tubes containing lithium heparin ( 7.5 units $/ \mathrm{ml}$ of added blood). The tubes were subsequently centrifuged within 30 minutes of its collection at $500 \mathrm{~g}$ for 15 minutes and the plasma was separated and stored at $-20^{\circ} \mathrm{C}$. Samples were analysed for total theophylline concentration, theophylline protein binding, and con- 
centrations of plasma albumin and non-esterified fatty acids. Total theophylline concentrations in the plasma were analysed by high performance liquid chromatography by a modification of the method of Orcutt et al, ${ }^{3}$ in which acetonitrile was replaced by methanol in the mobile phase $(30 \% \mathrm{v} / \mathrm{v})$ and the internal standard was 8-chlorotheophylline. Protein binding estimates were performed in duplicate. Two $1 \mathrm{ml}$ aliquots of plasma were added to duplicate teflon equilibrium dialysis cells (MSE Dianorm) separated by a Spectrapor 2 membrane from a Sørenson phosphate buffer, $\mathrm{pH} 7 \cdot 4$, containing $0.59 \% \mathrm{w} / \mathrm{v}$ sodium chloride; $180 \mathrm{ng} / \mathrm{ml}(1 \mu \mathrm{mol} / \mathrm{ml})$ of ${ }^{14} \mathrm{C}$ theophylline was added to the buffer and the cells were dialysed for two hours at $37^{\circ} \mathrm{C}$. No leakage of albumin was detected during the procedure; the binding of theophylline to the membrane was $2.96 \%$ (SD $0.62 \%$ ) and equilibrium was achieved at 90 minutes. The coefficient of variation of duplicate samples was $2.04 \%$. After dialysis two $300 \mu \mathrm{l}$ aliquots from each side of the cell were added to $5 \mathrm{ml}$ of scintillation fluid (Packard) and the radioactivity was measured with a Phillips PW 4540 scintillation counter. Quench correction was made by an external standards ratio method (counting efficiency about $83 \%$ ) and the percentage of unbound drug in the plasma was calculated as the ratio of the disintegration rate in buffer to that in plasma multiplied by 100 .

The free plasma theophylline concentration was calculated by multiplying total concentration by the fraction free in plasma. The total concentration of non-esterified fatty acids was measured by a modification of the method of Duncombe. ${ }^{4}$ Plasma albumin concentrations were estimated by nephelometry. ${ }^{5}$ Relationships between variables were examined by least squares linear regression analysis. In all cases $p<0.05$ is taken as the minimum level of statistical significance. Standard deviations are given in parentheses. Binding of drug is expressed as the ratio of bound to unbound drug (binding ratio). This ratio should be linearly related to the concentration of the binding protein (in this case albumin) provided that the dissociation constant of the drug-protein complex is much greater than the unbound drug concentration.

\section{Results}

The theophylline dose in the 39 patients varied from $175 \mathrm{mg}$ to $1000 \mathrm{mg}$ a day. The total plasma theophylline concentration varied from 0.7 to 22

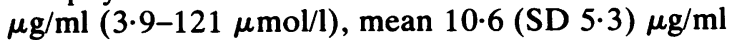
(58.3 (29.2) $\mu \mathrm{mol} / \mathrm{l})$; and it was not related to the total daily dose of theophylline $(r=0 \cdot 263, n=39, p$ $>0.05)$. The fraction of theophylline that was

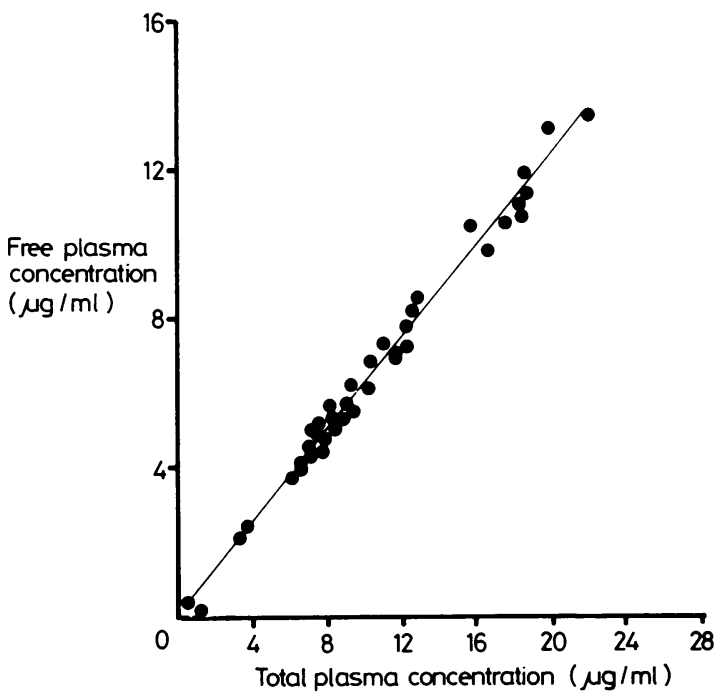

Fig 1 Relationship between the free (unbound) and total plasma theophylline concentration $(r=0.996, n=39, p<$ $0.001 ; y=0.612 x+0 \cdot 104)$.

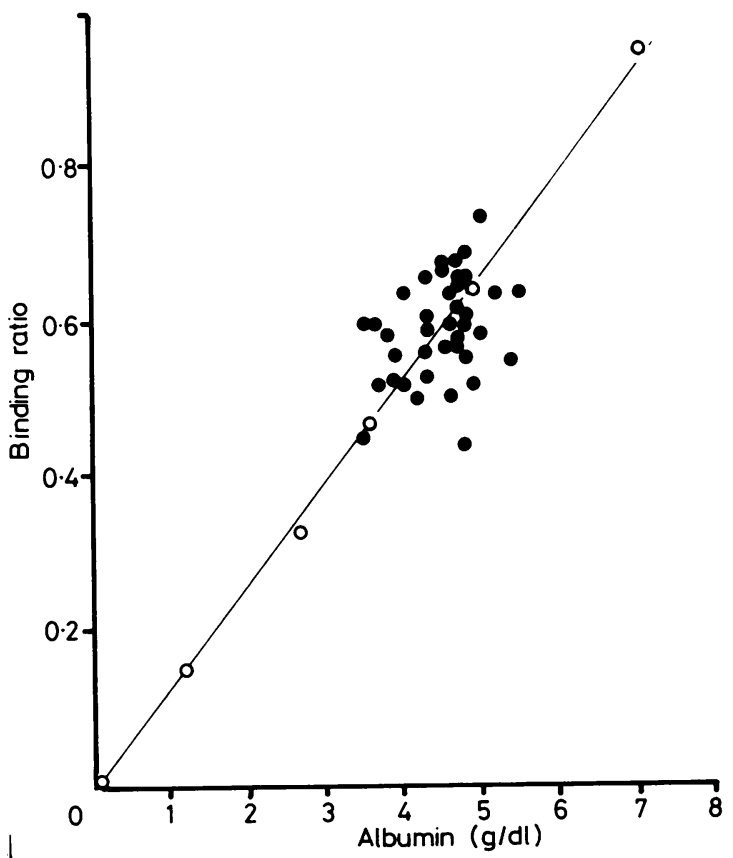

Fig 2 Relationship between theophylline binding (expressed as the ratio of bound to free drug binding ratio) and the serum albumin concentration in patients (closed circles: $r=0.409, n=39, p<0.01$ ) and in human serum albumin solutions (open circles: $r=0.998, n=6, p<$ $0.001 ; y=0.005 x+0.366)$. 
Table 1 Studies of the protein binding theophylline using ultrafiltration in patients with chronic airflow obstruction

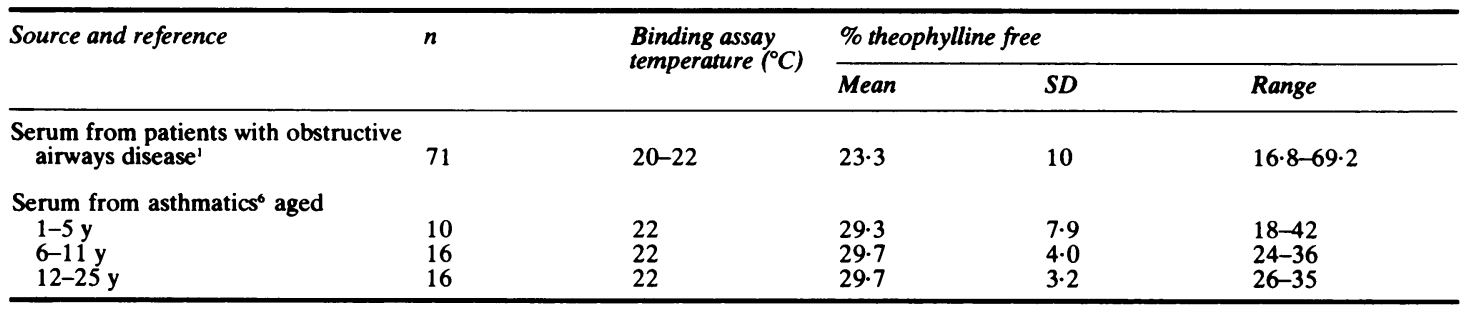

${ }^{*} \mathrm{pH}$ of binding assay not stated for any of the groups.

unbound varied from 0.575 to 0.688 (mean 0.626 $(0.024)$ and the distribution was consistent with normality. The fraction of unbound theophylline was not related to the total concentration of the drug $(r=-0 \cdot 225, n=39, p>0 \cdot 05)$. The free concentration of theophylline varied from 0.47 to $13.6 \mu \mathrm{g} / \mathrm{ml}$ $(2 \cdot 6-74 \cdot 8 \mu \mathrm{mol} / \mathrm{l})$. In view of the small variation in binding the free and total concentrations of theophylline were closely related $(r=0.996, n=$ $39, \mathrm{p}<0.001$ ) (fig 1). The albumin concentrations varied from $35 \mathrm{~g} / \mathrm{l}$ to $54 \mathrm{~g} / \mathrm{l}$ (mean $44 \cdot 2$ (6.1) $\mathrm{g} / \mathrm{l}$ ). The degree of binding, as expressed by the binding ratio, was related to the albumin concentration in both human serum albumin solutions of varying concentrations $(r=0.998, n=6, p<0.001)$ and the samples from patients $(r=0.409, n=39, p<$ 0.01 ) (fig 2). The binding ratio of theophylline was significantly, although weakly, negatively related to the patient's age $(r=-0 \cdot 349, \mathrm{n}=39, \mathrm{p}<0.05)$ The concentration of non-esterified fatty acids was $184-2239 \mu \mathrm{mol} / \mathrm{l}$ and the distribution was skewed to the right. Logarithmic transformation of the concentration of non-esterified fatty acids produced a distribution consistent with normality, but the natural logarithm of the concentration of nonesterified fatty acids was not related to the binding ratio of theophylline $(r=0 \cdot 218, n=39, p>0 \cdot 05)$.

\section{Discussion}

Two other studies of plasma protein binding in patients with chronic airflow obstruction have been undertaken and are summarised in table 1. The major criticism of these papers is the technique used to measure protein binding. All of the studies used ultrafiltration, which has recently been shown to have major drawbacks. The greatest problem concerns the control of the $\mathrm{pH}$ of samples since this is a major determinant of the degree of protein binding. ${ }^{278}$ Variation in $\mathrm{pH}$ of samples allowed to stand in the room or subjected to ultrafiltration without pH control may cause spuriously high variability. During equilibrium dialysis, on the other hand, control of $\mathrm{pH}$ is performed routinely. Secondly, ultrafiltration is often performed at room temperature or in a centrifuge at uncontrolled temperature. Temperature is an important determinant of theophylline binding 9 and protein binding tends to decrease with increasing temperature. Thirdly, ultrafiltration techniques can suffer considerably from variable non-specific binding to the drug membrane $^{10}$ and in none of the studies was this potential problem examined. We in contrast used equilibrium dialysis, in which the temperature and $\mathrm{pH}$ of samples can be controlled and in which non-specific binding to the membrane is low and of much less importance than with ultrafiltration..$^{10}$ Although, so far as we are aware, equilibrium dialysis techniques have not previously been used in studies of patients with chronic airflow obstruction, when these techniques have been used in normal volunteers less variability in plasma protein binding of theophylline is seen than when ultrafiltration techniques are used (table 2).

Table 2 Studies of the protein binding of theophylline using equilibrium dialysis in normal individuals and the patients of this study

\begin{tabular}{|c|c|c|c|c|c|c|}
\hline \multirow[t]{2}{*}{ Source and reference } & \multirow[t]{2}{*}{$n$} & \multirow{2}{*}{$\begin{array}{l}\text { Binding assay } \\
\text { temperature }\left({ }^{\circ} \mathrm{C}\right)\end{array}$} & \multirow{2}{*}{$\begin{array}{l}\text { Binding assay } \\
\text { pH }\end{array}$} & \multicolumn{3}{|c|}{ \% theophylline free } \\
\hline & & & & Mean & $S D$ & Range \\
\hline $\begin{array}{l}\text { Plasma, normal individuals }{ }^{2} \\
\text { Serum, normal individuals }{ }^{8} \\
\text { Serum, normal individuals } \\
\text { Plasma, normal individuals } \\
\text { Serum, normal individuals }{ }^{12} \\
\text { Plasma, patients with chronic airflow }\end{array}$ & $\begin{array}{r}24 \\
5 \\
10 \\
7 \\
10\end{array}$ & $\begin{array}{l}37 \\
22 \\
37 \\
37 \\
37\end{array}$ & $\begin{array}{l}7 \cdot 4 \\
7 \cdot 4-7 \cdot 5 \\
7 \cdot 4 \\
7 \cdot 4 \\
7 \cdot 4\end{array}$ & $\begin{array}{l}60 \cdot 0 \\
64 \cdot 2 \\
60 \cdot 7 \\
41 \cdot 0 \\
54 \cdot 4\end{array}$ & $\begin{array}{l}2 \cdot 2 \\
1 \cdot 4 \\
3 \cdot 4 \\
2 \cdot 8 \\
0 \cdot 8\end{array}$ & $\begin{array}{l}55-64 \\
62-66 \\
\text { Not given } \\
37-45 \\
\text { Not given }\end{array}$ \\
\hline obstruction (this study) & 39 & 37 & $7 \cdot 4$ & $62 \cdot 6$ & $2 \cdot 4$ & $58-69$ \\
\hline
\end{tabular}


It has already been shown that the protein binding of theophylline is significantly, although weakly, related to the plasma concentration of non-esterified fatty acids in normal individuals and that in vitro addition of non-esterified fatty acids to albumin solutions reduces plasma theophylline binding. ${ }^{2}$ The non-significant relationship between non-esterified fatty acids and theophylline binding may reflect the relatively narrow range of protein binding of theophylline seen and the obscuring effects of other, perhaps more important, factors on plasma theophylline binding.

The effect of age on plasma theophylline binding is also interesting. It is known that plasma albumin concentrations do fall with increasing age ${ }^{13}$; but analysis of the partial correlation coefficients of theophylline binding, albumin, and age suggests that there is an additional age related effect which is not associated with the falling albumin concentration. Possibly this is related to the known age related decline in renal function since patients with overt chronic renal failure have a much greater reduction in plasma protein binding of theophylline than would be expected from their plasma albumin concentration (D Leopold, personal communication). Nevertheless, we believe that the combined effects of non-esterified fatty acids, albumin, and age on the variability in plasma theophylline binding are relatively small and therefore of little clinical relevance in outpatients receiving long term treatment. These factors may, however, be more important in patients with acute exacerbations of their airflow obstruction or in those with liver or renal disease.

The clinical relevance of this small degree of variability in plasma protein binding is twofold. Firstly, even if drug response is more closely related to free than to total plasma concentration, the latter will closely reflect the former and in this group of patients direct measurement of free drug concentration is certainly unnecessary. Secondly, it would seem that the variation in clinical response seen between such patients at any given total plasma theophylline concentration cannot be explained on the grounds of variation in plasma protein binding of the drug; other factors must therefore be responsible.

We thank Dr RA Fifield for measurement of albumin concentrations and Napp Laboratories Ltd for financial assistance.

\section{References}

${ }^{1}$ Lesko LJ, Tabur KJ, Johnson BF. Theophylline serum protein binding in obstructive airways disease. Clin Pharmacol Ther 1981;29:776-81.

${ }^{2}$ Buss D, Leopold D, Smith AP, Routledge PA. Determinants of protein binding of theophylline in health. Br J Clin Pharmacol 1983;15:399-405.

${ }^{3}$ Orcutt JJ, Kozak PP, Gillman SA, Cummins LH. Microscale method for theophylline in body fluids by reversed-phase, high-pressure liquid chromatography. Clin Chem 1977;23:599-601.

${ }^{4}$ Duncombe WG. The colorimetric microdetermination of non esterified fatty acids in plasma. Clin Chim Acta 1964;9:122-5.

${ }^{5}$ Derry CK, Deaton CD, Gibbit MD. Immunonephelometric measurement of specific plasma proteins. Rircirca Clin Lab 1980;10:267-9.

' Simons KJ, Simon FER, Briggs CJ, Lo L. Theophylline protein binding in humans. $J$ Pharmacol Sci 1979;68:252-3.

7 Vallner JJ, Speir WA, Kolbeck RC, Harrison GN, Bransome ED. Effect of $\mathrm{pH}$ on the binding of theophylline to serum proteins. Am Rev Respir Dis 1979;120:83-6.

${ }^{8}$ Brørs O, Sager G, Sandres D, Jacobsen S. Binding of theophylline in human serum determined by ultrafiltration and equilibrium dialysis. $\mathrm{Br} \mathrm{J}$ Clin Pharmacol 1983;15:393-7.

${ }^{9}$ Shaw LM, Fields L, Maycock R. Factors influencing theophylline serum protein binding. Clin Pharmacol Ther 1982;32:490-6.

${ }^{10}$ Chignell CF. Protein binding. In: Garrett ER, Hirz L, eds. Drug fate metabolism methods and techniques. Vol 1. New York: Marcel Dekker, 1977: 187-228.

"Koysooko R, Ellis EF, Levy G. Relationship between theophylline concentration in plasma and saliva in man. Clin Pharmacol Ther 1974;15:454-60.

12 Fleetham JA, Bird CE, Nakatsu K, Wigle RD, Munt PW. Dose dependency theophylline clearance and protein binding. Thorax 1981;36:382-6.

${ }^{13}$ Woodford-Williams E, Alvarez AS, Webster D, Kandless B, Dixon MP. Serum protein patterns in normal and pathological ageing. Gerontologia 1964;10:86-9. 